\title{
Lifetime degradation of n-type Czochralski silicon after hydrogenation
}

DOI:

$10.1063 / 1.5011351$

Document Version

Final published version

Link to publication record in Manchester Research Explorer

\section{Citation for published version (APA):}

Vaqueiro Contreras, M., Markevich, V., Mullins, J., Halsall, M., Murin, L. I., Falster, R., Binns, J., Coutinho, J., \& Peaker, A. (2018). Lifetime degradation of n-type Czochralski silicon after hydrogenation. Journal of Applied Physics, 123, [161415]. https://doi.org/10.1063/1.5011351

\section{Published in:}

Journal of Applied Physics

\section{Citing this paper}

Please note that where the full-text provided on Manchester Research Explorer is the Author Accepted Manuscript or Proof version this may differ from the final Published version. If citing, it is advised that you check and use the publisher's definitive version.

\section{General rights}

Copyright and moral rights for the publications made accessible in the Research Explorer are retained by the authors and/or other copyright owners and it is a condition of accessing publications that users recognise and abide by the legal requirements associated with these rights.

\section{Takedown policy}

If you believe that this document breaches copyright please refer to the University of Manchester's Takedown Procedures [http://man.ac.uk/04Y6Bo] or contact uml.scholarlycommunications@manchester.ac.uk providing relevant details, so we can investigate your claim.

\section{OPEN ACCESS}




\section{Lifetime degradation of $\mathbf{n}$-type Czochralski silicon after hydrogenation}

M. Vaqueiro-Contreras, V. P. Markevich, J. Mullins, M. P. Halsall, L. I. Murin, R. Falster, J. Binns, J. Coutinho, and A. R. Peaker

Citation: Journal of Applied Physics 123, 161415 (2018); doi: 10.1063/1.5011351

View online: https://doi.org/10.1063/1.5011351

View Table of Contents: http://aip.scitation.org/toc/jap/123/16

Published by the American Institute of Physics

\section{Articles you may be interested in}

Tutorial: Junction spectroscopy techniques and deep-level defects in semiconductors Journal of Applied Physics 123, 161559 (2018); 10.1063/1.5011327

Theoretical insights into the minority carrier lifetime of doped Si-A computational study Journal of Applied Physics 123, 161420 (2018); 10.1063/1.5010045

Impact of interstitial iron on the study of meta-stable B-O defects in Czochralski silicon: Further evidence of a single defect

Journal of Applied Physics 123, 161586 (2018); 10.1063/1.5000323

Characterization of iron in silicon by low-temperature photoluminescence and deep-level transient spectroscopy Journal of Applied Physics 123, 105101 (2018); 10.1063/1.5019958

Recombination parameters of lifetime-limiting carrier-induced defects in multicrystalline silicon for solar cells Applied Physics Letters 110, 092106 (2017); 10.1063/1.4977906

Light-induced activation and deactivation of bulk defects in boron-doped float-zone silicon Journal of Applied Physics 121, 185702 (2017); 10.1063/1.4983024

\section{PHYSICS TODAY}

WHITEPAPERS
MANAGER'S GUIDE

Accelerate R\&D with

Multiphysics Simulation

\section{READ NOW}

PRESENTED BY

И口ОMSOL 


\title{
Lifetime degradation of n-type Czochralski silicon after hydrogenation
}

\author{
M. Vaqueiro-Contreras, ${ }^{1}$ V. P. Markevich, ${ }^{1}$ J. Mullins, ${ }^{1}$ M. P. Halsall, ${ }^{1}$ L. I. Murin, ${ }^{2}$ R. Falster, ${ }^{3}$ \\ J. Binns, ${ }^{4}$ J. Coutinho, ${ }^{5}$ and A. R. Peaker ${ }^{1}$ \\ ${ }^{1}$ Photon Science Institute, University of Manchester, Manchester M13 9PL, United Kingdom \\ ${ }^{2}$ Materials Research Center NAS, Minsk 220072, Belarus \\ ${ }^{3}$ SunEdison Semiconductor, Ltd., viale Gherzi 31, 28100 Novara, Italy \\ ${ }^{4}$ SunEdison Inc., 7832 N. Leadbetter Rd., Portland, Oregon 97203, USA, [Now owned by GCL Solar \\ Materials, 7833 North Leadbetter Road, Portland, Oregon, 97203 USA] \\ ${ }^{5}$ Department of Physics and I3N, University of Aveiro, Aveiro 3810-193, Portugal
}

(Received 31 October 2017; accepted 21 February 2018; published online 14 March 2018)

\begin{abstract}
Hydrogen plays an important role in the passivation of interface states in silicon-based metal-oxide semiconductor technologies and passivation of surface and interface states in solar silicon. We have shown recently [Vaqueiro-Contreras et al., Phys. Status Solidi RRL 11, 1700133 (2017)] that hydrogenation of n-type silicon slices containing relatively large concentrations of carbon and oxygen impurity atoms $\left\{\left[\mathrm{C}_{\mathrm{s}}\right] \geq 1 \times 10^{16} \mathrm{~cm}^{-3}\right.$ and $\left.\left[\mathrm{O}_{\mathrm{i}}\right] \geq 10^{17} \mathrm{~cm}^{-3}\right\}$ can produce a family of C-O-H defects, which act as powerful recombination centres reducing the minority carrier lifetime. In this work, evidence of the silicon's lifetime deterioration after hydrogen injection from $\operatorname{SiN}_{\mathrm{x}}$ coating, which is widely used in solar cell manufacturing, has been obtained from microwave photoconductance decay measurements. We have characterised the hydrogenation induced deep level defects in n-type Czochralski-grown Si samples through a series of deep level transient spectroscopy (DLTS), minority carrier transient spectroscopy (MCTS), and high-resolution Laplace DLTS/MCTS measurements. It has been found that along with the hydrogen-related hole traps, $\mathrm{H}_{1}$ and $\mathrm{H}_{2}$, in the lower half of the gap reported by us previously, hydrogenation gives rise to two electron traps, $\mathrm{E}_{1}$ and $E_{2}$, in the upper half of the gap. The activation energies for electron emission from the $E_{1}$ and $\mathrm{E}_{2}$ trap levels have been determined as 0.12 , and $0.14 \mathrm{eV}$, respectively. We argue that the $\mathrm{E}_{1} / \mathrm{H}_{1}$ and $\mathrm{E}_{2} / \mathrm{H}_{2}$ pairs of electron/hole traps are related to two energy levels of two complexes, each incorporating carbon, oxygen, and hydrogen atoms. Our results show that the detrimental effect of the $\mathrm{C}-\mathrm{O}-\mathrm{H}$ defects on the minority carrier lifetime in n-type $\mathrm{Si} \mathrm{O}+\mathrm{C}$ materials can be very significant, and the carbon concentration in Czochralski-grown silicon is a key parameter in the formation of the recombination centers. (C) 2018 Author(s). All article content, except where otherwise noted, is licensed under a Creative Commons Attribution (CC BY) license (http://creativecommons.org/ licenses/by/4.0/). https://doi.org/10.1063/1.5011351
\end{abstract}

\section{INTRODUCTION}

Hydrogen has been used for over 50 years in the semiconductor industry to passivate surface and interface states by satisfying dangling bonds. This was the important breakthrough in the $1970 \mathrm{~s},{ }^{1}$ which enabled metal-oxide-semiconductor (MOS) and complementary MOS (CMOS) signal processing devices to be made reproducibly and is still an important part in the processing of modern microelectronic devices ranging from semiconductor memory to processor chips. ${ }^{2}$ Hydrogen passivation of interface states and recombination centers in multicrystalline and crystalline silicon materials has also been successfully used in solar cell processing ${ }^{3-6}$ and has become a part of solar silicon research and technologies. ${ }^{78}$ Such passivation results in fewer carriers being lost at the surface of the silicon solar cell, at the interface with the anti-reflection dielectric layers, and in the solar material bulk thereby contributing to increased cell efficiencies. Achieving higher efficiencies of solar cells has become the prime target for the solar cell industry as discussed in a recent review paper by Green. ${ }^{9}$

However, somewhat surprisingly we have found recently that hydrogen atoms can react with carbon-oxygen-related defects in silicon to produce powerful recombination centers, which reduce the minority carrier lifetime in n-type silicon containing $\mathrm{O}$ impurity atoms and higher than usual concentrations of $\mathrm{C}$, thereby reducing the efficiency of any solar cells made from such material. ${ }^{10,11}$ We have reported the observation of two very powerful recombination centers, $\mathrm{H}_{1}$ and $\mathrm{H}_{2}$, formed by carbon-oxygen and hydrogen $(\mathrm{C}-\mathrm{O}-\mathrm{H})$ interactions in a range of n-type Czochralski $(\mathrm{Cz}) \mathrm{Si}$ materials grown by conventional and continuous Czochralski $(\mathrm{C}-\mathrm{Cz})$ techniques. ${ }^{11}$ These types of materials are gaining ground in the solar industry for high efficiency products because of a number of beneficial properties compared to p-type silicon. They have, particularly, a higher "as grown" lifetime, lesser sensitivity to metallic contaminations, and negligible light induced degradation. ${ }^{12,13}$ However, the oxygen concentration is high $\left(\geq 5 \times 10^{17} \mathrm{~cm}^{-3}\right)$ in Czochralski-grown silicon, and some $\mathrm{Cz}$ and $\mathrm{C}$-Cz-Si materials grown for solar applications contain rather high $\left(>2 \times 10^{16} \mathrm{~cm}^{-3}\right)$ concentration of carbon atoms. As hydrogen is frequently encountered in the silicon solar materials either by deliberate introduction or as a result of wafer processing, the likelihood of the formation of the C-O$\mathrm{H}$ complexes is quite significant in $\mathrm{n}$-type $\mathrm{Cz}-\mathrm{Si}$ and $\mathrm{C}-\mathrm{Cz}-\mathrm{Si}$, thereby making the solar cells from these materials more susceptible to an efficiency decrease if the $\mathrm{C}-\mathrm{O}-\mathrm{H}$ reaction can 
progress and the complex retained in the finished product. It has been found that like many other H-related defects in silicon, the $\mathrm{H}_{1} / \mathrm{H}_{2}$ recombination centers anneal out at quite low temperatures, and they have been shown to be eliminated after a 30-min heat-treatment at $175^{\circ} \mathrm{C} .{ }^{10}$ However, as we have suggested in Refs. 10 and 11, when enough hydrogen is present in hydrogenated solar cells, the C-O-H complexes can reform upon cooling the cells after heat treatments at $\mathrm{T} \geq 200^{\circ} \mathrm{C}$ and thereby reduce the cell efficiency.

In the present work, we show the results of a series of microwave photoconductance decay $(\mu \mathrm{PCD})$ measurements, which validate the earlier suggestion and demonstrate lifetime deterioration in n-type $\mathrm{Cz}-\mathrm{Si}$ samples after hydrogen injection from $\mathrm{SiN}_{\mathrm{x}}$ coating, which is widely used in solar cell manufacturing, and after the introduction of hydrogen by other methods. Further, it is shown that along with the hydrogenrelated $\mathrm{H}_{1}$ and $\mathrm{H}_{2}$ hole traps in the lower half of the gap, hydrogenation of n-type $\mathrm{Cz}-\mathrm{Si}$ samples give rise to two electron traps $\left(E_{1}\right.$ and $\left.E_{2}\right)$ in the upper half of the gap. These electron traps have been characterized and their origin is discussed.

\section{EXPERIMENTAL DETAILS}

We have carried out measurements of minority carrier lifetime and characterization of deep level defects on samples from a wide range of n-type phosphorus doped $\mathrm{Cz}-$ and $\mathrm{C}-\mathrm{Cz}-\mathrm{Si}$ wafers with resistivity between 1 and $8 \Omega \mathrm{cm}$. The concentration of interstitial oxygen atoms, $\left[\mathrm{O}_{\mathrm{i}}\right]$, was in the range from 12 to 20 ppma $\left(1 \mathrm{ppma}=5 \times 10^{16} \mathrm{~cm}^{-3}\right)$, while the concentration of substitutional carbon atoms, $\left[\mathrm{C}_{\mathrm{s}}\right]$, varied from 0.01 to 9 ppma in the samples studied. Also a few float zone (FZ) grown silicon samples with $\left[\mathrm{O}_{\mathrm{i}}\right]<0.2$ ppma have been studied for a comparison. The samples were cut and RCA cleaned, and hydrogen was then introduced into the silicon by three different techniques: (1) wet etching with either $\mathrm{KOH}$ or $\mathrm{HF} / \mathrm{HNO}_{3}$ solution, (2) $50 \mathrm{~W}$ remote $\mathrm{H}$ plasma exposure for $30 \mathrm{~min}$ at temperatures between 25 and $250^{\circ} \mathrm{C}$, and (3) in-diffusion of hydrogen from $\mathrm{H}$-rich silicon nitride $\left(\mathrm{SiN}_{\mathrm{x}}: \mathrm{H}\right)$ films. $\mathrm{SiN}_{\mathrm{x}}: \mathrm{H}$ films were deposited by the Plasma-Enhanced Chemical Vapour Deposition (PECVD) technique, in a PlasmaPro 100 PECVD system, using Oxford Instruments. The deposition parameters were: $20: 20 \mathrm{sccm} \mathrm{SiH}_{4}: \mathrm{NH}_{3}$ gas flow, 300 mTorr chamber pressure, $400{ }^{\circ} \mathrm{C}$ table temperature, $13.56 \mathrm{MHz}$ plasma generated frequency, and $50 \mathrm{~W}$ of power. These parameters produced a $90 \mathrm{~nm} \mathrm{SiN}$ : $\mathrm{H}$ film after $2 \mathrm{~min}$ of plasma exposure, which was then etched off in an Oxford Instruments System 100180 RIE system before measurements of minority carrier lifetime. For etching the $\mathrm{SiN}_{\mathrm{x}}: \mathrm{H}$ films, the samples were exposed for $50 \mathrm{~s}$ to a $6 \mathrm{~W}$ RF plasma plus a $600 \mathrm{~W}$ inductively coupled plasma (ICP) of $\mathrm{O}_{2}: \mathrm{CHF}_{3}: \mathrm{CF}_{4}(2: 10: 23 \mathrm{sccm})$ gas, at 13.56 MHz. The annealing of the samples, aimed at the dissociation of the hydrogen-related recombination active defects, has been carried at $200^{\circ} \mathrm{C}$ in an oven in air ambient.

The microwave photoconductivity decay ( $\mu \mathrm{PCD}$ ) lifetime mapping was carried out with the use of a Semilab WT-2000 PVN machine, which has $905 \mathrm{~nm}$ LASER excitation and a microwave source operating at $\sim 10 \mathrm{GHz}$. The lifetime maps thus represent an averaged lifetime in the sample at a depth of a few tens of microns from the surface. For suppression of surface recombination, the maps were recorded with both surfaces of the samples covered with iodine/ethanol solution. ${ }^{14}$

For deep level transient spectroscopy (DLTS) and minority carrier transient spectroscopy (MCTS) measurements, ${ }^{15}$ the samples were cleaned and subjected to evaporation of Au through a shadow mask from the front side and to Al evaporation without mask on the back side, to produce Schottky barrier diodes and an Ohmic contact, respectively. An un-metalized region of the Ohmic contact was left on the back of the MCTS samples to allow an optical excitation from a $940 \mathrm{~nm}$ light emitting diode (LED). Each diode was characterized first with the current-voltage and capacitancevoltage measurements, and subsequently DLTS, MCTS, and high resolution Laplace DLTS/MCTS ${ }^{16}$ measurements were carried out for the detection and characterization of electrically active defects.

\section{EXPERIMENTAL RESULTS AND DISCUSSION}

\section{A. Effect of hydrogenation treatments on minority carrier lifetime in n-type $\mathbf{C z}-\mathrm{Si}$}

We have carried out a series of $\mu \mathrm{PCD}$ measurements to observe the reduction of the minority carrier lifetime induced by hydrogen introduction with different methods into an $\mathrm{n}-\mathrm{Si}$ sample with $\left[\mathrm{O}_{\mathrm{i}}\right]=7.5 \times 10^{17} \mathrm{~cm}^{-3},\left[\mathrm{C}_{\mathrm{s}}\right]=4.5 \times 10^{17} \mathrm{~cm}^{-3}$, and $2 \mathrm{~mm}$ thickness. Figure 1 shows a set of minority carrier lifetime maps recorded on the $\mathrm{Si}: \mathrm{O}+\mathrm{C}$ sample, which was subjected to the following subsequent hydrogenation treatments: (a) wet etching in $1 \mathrm{HF}+7 \mathrm{HNO}_{3}$ solution for $3 \mathrm{~min}$ at room temperature (RT), (b) $50 \mathrm{~W}$ remote $\mathrm{H}$ plasma exposure for $30 \mathrm{~min}$ at $\mathrm{RT}$, (c) wet etching in $20 \% \mathrm{KOH}$ solution for $10 \mathrm{~min}$ at $60^{\circ} \mathrm{C}$. Figure 1 also shows a lifetime map recorded on the other side of the same sample after in-diffusion of hydrogen from $\mathrm{H}$-rich silicon nitride $\left(\mathrm{SiN}_{\mathrm{x}}: \mathrm{H}\right)$ films (the deposition temperature was $400^{\circ} \mathrm{C}$ ). All the maps were recorded immediately after each hydrogenation treatment and then after annealing at $200^{\circ} \mathrm{C}$ for $20 \mathrm{~min}$ to destroy the $\mathrm{C}-\mathrm{O}-\mathrm{H}$ complexes.

An inspection of the lifetime maps in Fig. 1 shows that each hydrogenation step resulted in the lifetime degradation of the material and its partial recovery after the heat treatments at $200^{\circ} \mathrm{C}$. Further, some decrease in the averaged lifetime $\left(\tau_{\mathrm{av}}\right)$ occurred in the course of the subsequent hydrogenationannealing steps from the first cycle with $\mathrm{HF} / \mathrm{HNO}_{3}$ etching $\left(\tau_{\mathrm{av}}=273 \mu \mathrm{s}\right)$ to the last one with $\mathrm{KOH}$ etching $\left(\tau_{\mathrm{av}}=111 \mu \mathrm{s}\right)$. Such a reduction can be associated with the accumulated introduction of hydrogen into the sample after each hydrogenation step, thereby making the thermally induced recovery of lifetime more difficult after each of the subsequent hydrogenationannealing cycles. The depth of the hydrogen penetration into the sample upon the $\mathrm{SiN}_{\mathrm{x}}: \mathrm{H}$ film deposition procedure is greater than in any other hydrogenation treatments used in this study because of the higher processing temperature, so it is likely that the recombination active $\mathrm{C}-\mathrm{O}-\mathrm{H}$ complexes have been re-formed in the SiN-processed sample during cooling down after the $200{ }^{\circ} \mathrm{C}$ annealing. The re-formed $\mathrm{C}-\mathrm{O}-\mathrm{H}$ complexes are responsible for the low $\tau_{\mathrm{av}}$ value, $117 \mu \mathrm{s}$, after the recovery annealing treatment. The results of lifetime mapping presented in Fig. 1 validate the idea suggested in Refs. 10 and 11 regarding the recovery of the $\mathrm{C}-\mathrm{O}-\mathrm{H}$ 

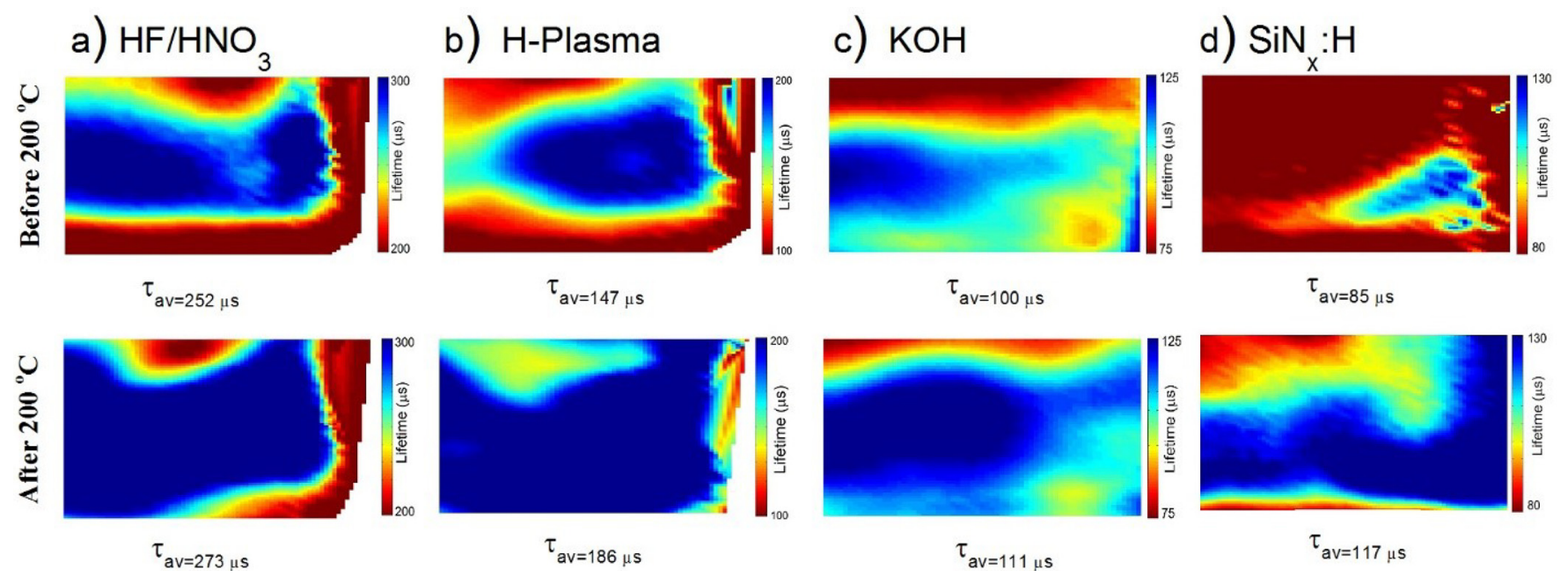

FIG. 1. Lifetime maps of an n-Si sample with $\left[\mathrm{O}_{\mathrm{i}}\right]=7.5 \times 10^{17} \mathrm{~cm}^{-3},\left[\mathrm{C}_{\mathrm{s}}\right]=4.5 \times 10^{17} \mathrm{~cm}^{-3}$, and $2 \mathrm{~mm}$ thickness recorded with the use of Semilab WT-2000 $\mathrm{PVN}$ machine and iodine/ethanol surface passivation after hydrogenation with four different methods and subsequent heat-treatments at $200^{\circ} \mathrm{C}$ for 20 min to destroy the $\mathrm{C}-\mathrm{O}-\mathrm{H}$ recombination centers.

complexes upon cooling down the n-type $\mathrm{Si}: \mathrm{O}+\mathrm{C}$ samples after their heat-treatments at temperatures higher than $200^{\circ} \mathrm{C}$ when enough hydrogen is present in the samples. It is very likely that the $\mathrm{C}-\mathrm{O}-\mathrm{H}$ complexes can survive in n-type $\mathrm{Cz}-\mathrm{Si}$ based solar cells throughout the manufacture processing, which incorporate a $\mathrm{SiN}_{\mathrm{x}}: \mathrm{H}$ film deposition step, thereby resulting in a reduction of efficiency of the finished solar cells.

\section{B. Electronic properties of the hydrogenation induced electron traps in $\mathrm{n}$-type $\mathrm{Cz}-\mathrm{Si}$ and their possible origin}

In our previous paper, ${ }^{10}$ the DLTS and MCTS spectra for one of the hydrogenated n-type $\mathrm{Si}: \mathrm{C}+\mathrm{O}$ samples have been shown. In the DLTS spectra, four peaks due to electron traps labelled as $\mathrm{E}_{1}$ to $\mathrm{E}_{4}$ have been detected, and in the MCTS spectra, four negative peaks due to hole traps labelled as $\mathrm{H}_{1}$ to $\mathrm{H}_{4}$ have occurred. These peaks can be seen in Figs. 2, 4, and 5 in the present paper. In Ref. 11, we have characterized and identified the dominant hole traps, $\mathrm{H}_{1}$ and $\mathrm{H}_{2}$, in hydrogenated n-type Cz-Si samples. From a series of Laplace MCTS measurements, the positions of energy levels of the $\mathrm{H}_{1}$ and $\mathrm{H}_{2}$ traps have been determined as $E_{\mathrm{v}}+0.38 \mathrm{eV}$ and $E_{\mathrm{v}}+0.36 \mathrm{eV}$, respectively, and the ratios of the capture cross sections of minority (holes) and majority (electrons) carriers as 50 and 40 , respectively. ${ }^{11}$ The measured parameters indicate that both the $\mathrm{H}_{1}$ and $\mathrm{H}_{2}$ traps are related to the acceptor levels of two defects, which are powerful recombination centers for holes in n-type $\mathrm{Si}$ crystals and are responsible for the lifetime degradation in the hydrogenated n-type Cz-Si crystals. We have demonstrated the involvement of carbon, oxygen, and hydrogen atoms in the formation of centers responsible for the $\mathrm{H}_{1}$ and $\mathrm{H}_{2}$ traps, and with the use of low temperature infrared absorption measurements, it has been found that a complex consisting of a substitutional carbon and an interstitial oxygen atom $(\mathrm{C}-\mathrm{O})$ is a pre-cursor of these defects. ${ }^{11}$ The possible structures of the $\mathrm{C}-\mathrm{O}-\mathrm{H}$ complex with electronic properties close to those for the $\mathrm{H}_{1}$ and $\mathrm{H}_{2}$ traps have been found from the first principles calculations. ${ }^{11,17}$
Here, we present results of a study of the electronic properties and thermal stability of the $\mathrm{E}_{1}, \mathrm{E}_{2}$, and $\mathrm{E}_{4}$ electron traps and some results on the relation of these traps to the most abundant oxygen, carbon, and hydrogen impurities. It should be noted, however, that the $E_{1}-E_{4}$ traps do not appear to be the significant recombination centers for holes in n-type Si crystals because of the closeness of their energy levels to the conduction band edge.

Figure 2 shows the development of the DLTS and MCTS spectra upon 30-min isochronal annealing of a hydrogenated n-type $\mathrm{Cz}$-Si sample in the temperature range from $50{ }^{\circ} \mathrm{C}$ to $200{ }^{\circ} \mathrm{C}$. It can be seen that the annealing behaviour of the $E_{1}$ and $E_{2}$ electron traps is similar to that of the $\mathrm{H}_{1} / \mathrm{H}_{2}$ hole traps. Both pairs of traps disappear upon heattreatments in the temperature range of $150-175^{\circ} \mathrm{C}$. In contrast, the magnitude of the peak related to the $\mathrm{E}_{4}$ trap has increased after the $150{ }^{\circ} \mathrm{C}$ and $175^{\circ} \mathrm{C}$ annealing steps. The $\mathrm{E}_{4}$ trap has been assigned in our previous work (Ref. 10) to the second donor level of the oxygen-related thermal double donors (TDDs). ${ }^{18}$ Even though hydrogen can passivate TDDs, the binding energy of $\mathrm{H}$ atoms to the TDDs centers is not high, and the electrical activity of TDDs is restored after heat-treatments in the temperature range of $150-175^{\circ} \mathrm{C} .{ }^{19}$ We have roughly estimated the activation energy for the $\mathrm{E}_{4}$ trap recovery from the isochronal annealing data in Fig. 2 and obtained the value of $1.65 \pm 0.05 \mathrm{eV}$, which is close to that found in Ref. 19 for the elimination of the TDD-H complexes. So, our results on the annealing behavior of the $\mathrm{E}_{4}$ trap validate the assignment of this trap to TDDs and are consistent with the previous DLTS results on TDDs and their passivation with hydrogen. ${ }^{18,19}$

The similarity in the elimination behaviour of the $\mathrm{E}_{1} / \mathrm{H}_{1}$ and $\mathrm{E}_{2} / \mathrm{H}_{2}$ trap pairs (Fig. 2) suggests that these pairs can be related to two energy levels of two defects. Later on, we present some results, which confirm this suggestion. Figure 3 shows the concentration profiles of the $\mathrm{H}_{2}$ and $\mathrm{E}_{2}$ traps in a Cz-Si sample, which was subjected to etching in $1 \mathrm{HF}+7 \mathrm{HNO}_{3}$ solution for $3 \mathrm{~min}$ at room temperature. The profiles have been obtained with the use of Laplace DLTS/MCTS techniques; however, the 

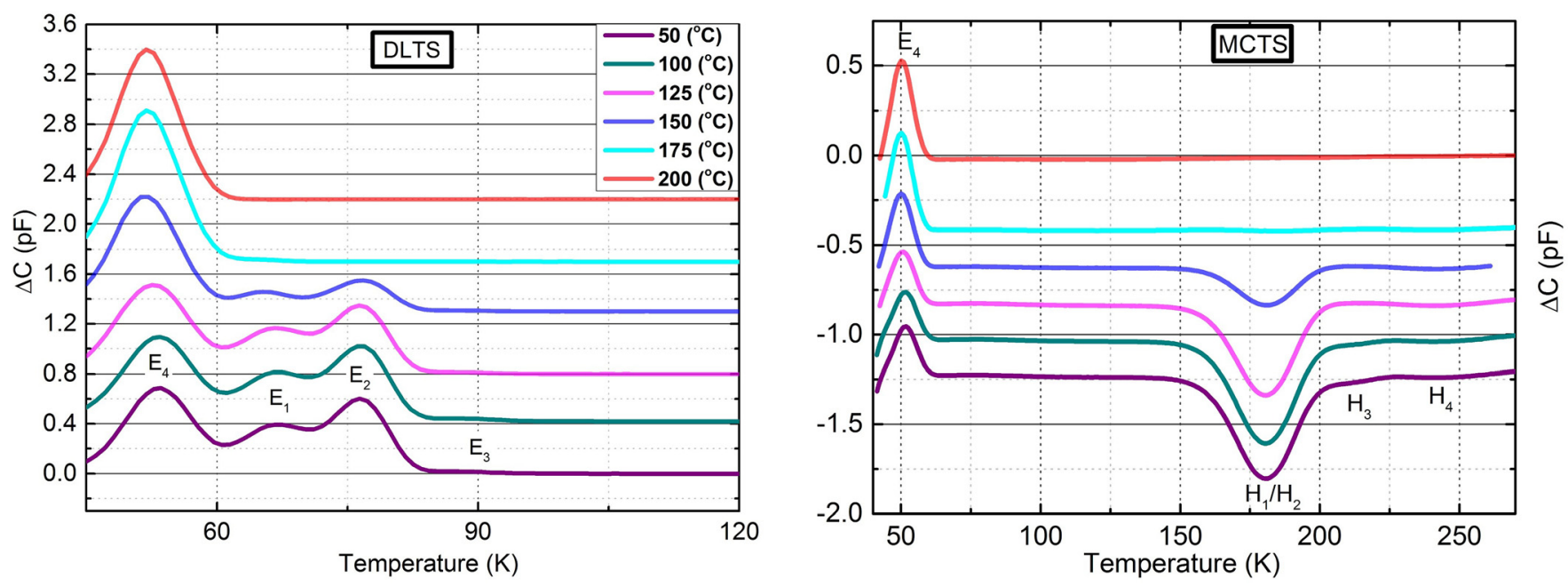

FIG. 2. DLTS and MCTS spectra of a hydrogenated n-type Cz-Si sample, which was subjected to 30-min isochronal annealing in the temperature range of $50^{\circ} \mathrm{C}$ to $200^{\circ} \mathrm{C}$. The spectra are shifted on the vertical axis for clarity. Hydrogen was introduced into the sample by etching in $1 \mathrm{HF}+7 \mathrm{HNO} \mathrm{H}_{3}$ solution for $3 \mathrm{~min}$ at room temperature.

measurement conditions for the $\mathrm{E}_{2}$ and $\mathrm{H}_{2}$ traps were different. The concentration profile for the $\mathrm{E}_{2}$ trap has been obtained using L-DLTS by changing both bias and pulse voltages $\left(U_{\mathrm{b}}\right.$ and $U_{\mathrm{p}}$, respectively) and a fixed difference between $U_{\mathrm{b}}$ and $U_{\mathrm{p}}$. So, the concentration values for the $\mathrm{E}_{2}$ trap have been determined in nearly equidistant relatively narrow probing areas. ${ }^{20,21}$ In MCTS measurements, only the reverse bias can be changed, and the probing area for minority carrier traps extends from the junction $\left(W_{1}=0\right)$ to the depletion depth under reverse bias $\left(W_{2}=W_{\mathrm{b}}\right)$. So, the concentration values for the $\mathrm{H}_{2}$ trap in Fig. 3 are the mean concentration values for the relatively wide probing areas (e.g. the deepest point for the $\mathrm{H}_{2}$ trap

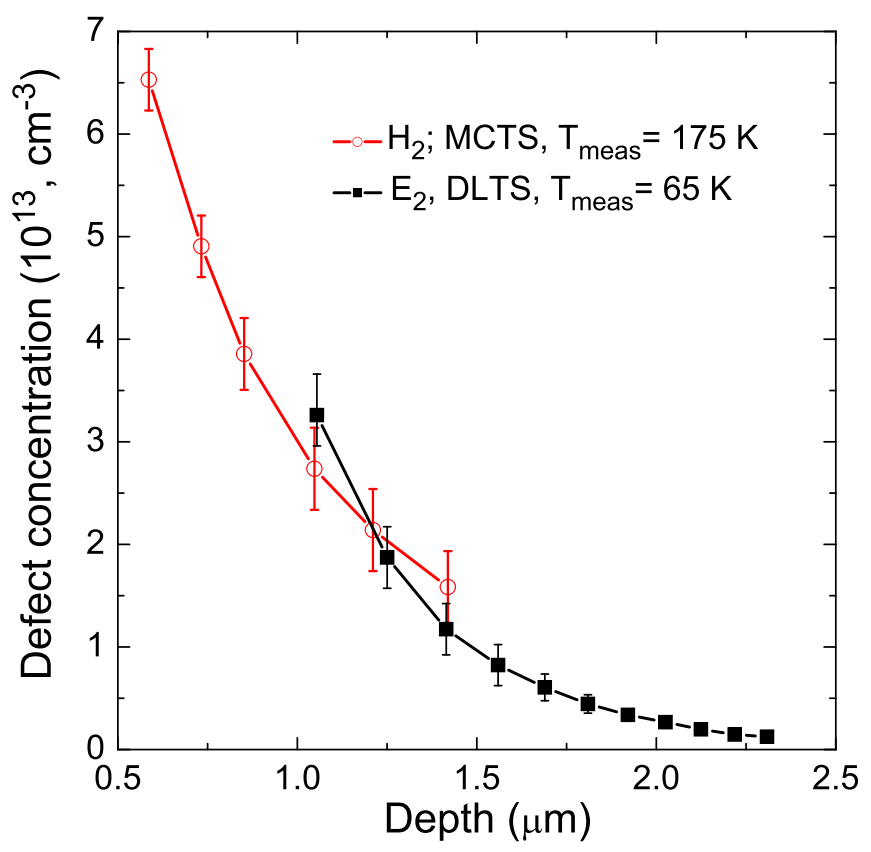

FIG. 3. Concentration profiles of the $\mathrm{H}_{2}$ hole traps and $\mathrm{E}_{2}$ electron trap in a $\mathrm{Cz}-\mathrm{Si}$ sample. Hydrogen was introduced into the sample by etching in $1 \mathrm{HF}+7 \mathrm{HNO}_{3}$ solution for $3 \mathrm{~min}$ at room temperature. The profiles were measured with the use of L-DLTS and L-MCTS techniques for the $\mathrm{E}_{2}$ and $\mathrm{H}_{2}$ traps, respectively. Further details of the measurements and analysis are given in the text. concentration in Fig. 3 corresponds to the mean concentration in a region between 0 and $2.85 \mu \mathrm{m}$ ). Taking into account the earlier and other possible sources of errors in the determination of minority carrier trap concentration using MCTS measurements, ${ }^{15,22}$ it appears that the profiles presented in Fig. 3 are almost certainly related to the same defect. The profiles are characteristics of the defects induced by hydrogen in-diffusion during wet chemical etching of n-type Si samples. ${ }^{10,23-25}$

The $E_{1}$ and $E_{2}$ electron traps have been observed in the DLTS spectra of hydrogenated Cz-Si samples but not in the spectra of hydrogenated FZ-Si samples. This observation indicates an involvement of oxygen impurity atoms into the corresponding defect structures. We have further investigated the possible links of the $\mathrm{E}_{1}$ and $\mathrm{E}_{2}$ electron traps to carbon and oxygen impurities. In Fig. 4, the DLTS and MCTS spectra are compared for four hydrogenated as-grown n-type $\mathrm{Cz}$ samples with different $\mathrm{C}_{\mathrm{s}}$ and nearly equal $\mathrm{O}_{\mathrm{i}}$ concentrations. In order to take into account the differences in resistivity of the samples studied, we have plotted the value of $2 \times N_{\mathrm{d}} \times \Delta C / C_{\mathrm{b}}$ on the vertical axis of Fig. 4, where $\Delta C$ is the magnitude of a capacitance change related to carrier emission from traps, $N_{\mathrm{d}}$ is the concentration of doping atoms, and $C_{\mathrm{b}}$ is the bias capacitance. Figure 4 show similar changes in concentrations of the $E_{1}$ and $\mathrm{E}_{2}$ electron traps and $\mathrm{H}_{1} / \mathrm{H}_{2}$ hole traps with changes in the carbon concentration in the samples. It should be noted here that the dependence of the concentration of the $\mathrm{C}-\mathrm{O}$ complex on $\left[\mathrm{C}_{\mathrm{s}}\right]$ and $\left[\mathrm{O}_{\mathrm{i}}\right]$ values is not straightforward, as the $[\mathrm{C}-\mathrm{O}]$ value depends on thermal prehistory of Si samples. ${ }^{11,26-28}$ It is possible to change the [C-O] value significantly by heat-treatments of the $\mathrm{Si}: \mathrm{O}+\mathrm{C}$ samples in the temperature range of $500-800^{\circ} \mathrm{C} .^{27,28}$ The DLTS and MCTS spectra presented in Fig. 5 show similar changes in the concentration of the $E_{1} / E_{2}$ electron traps and $\mathrm{H}_{1} / \mathrm{H}_{2}$ hole traps in samples from a carbon and oxygen rich $\mathrm{Si}$ material, which were subjected to heattreatments in the temperature range of $500-750^{\circ} \mathrm{C}$ with subsequent hydrogenation.

A comparison of the introduction and annealing behaviours of the $\mathrm{E}_{1}$ and $\mathrm{E}_{2}$ electron traps and $\mathrm{H}_{1}$ and $\mathrm{H}_{2}$ hole traps (Figs. 2-5) strongly indicates that the $\mathrm{E}_{1} / \mathrm{H}_{1}$ and $\mathrm{E}_{2} / \mathrm{H}_{2}$ pairs 


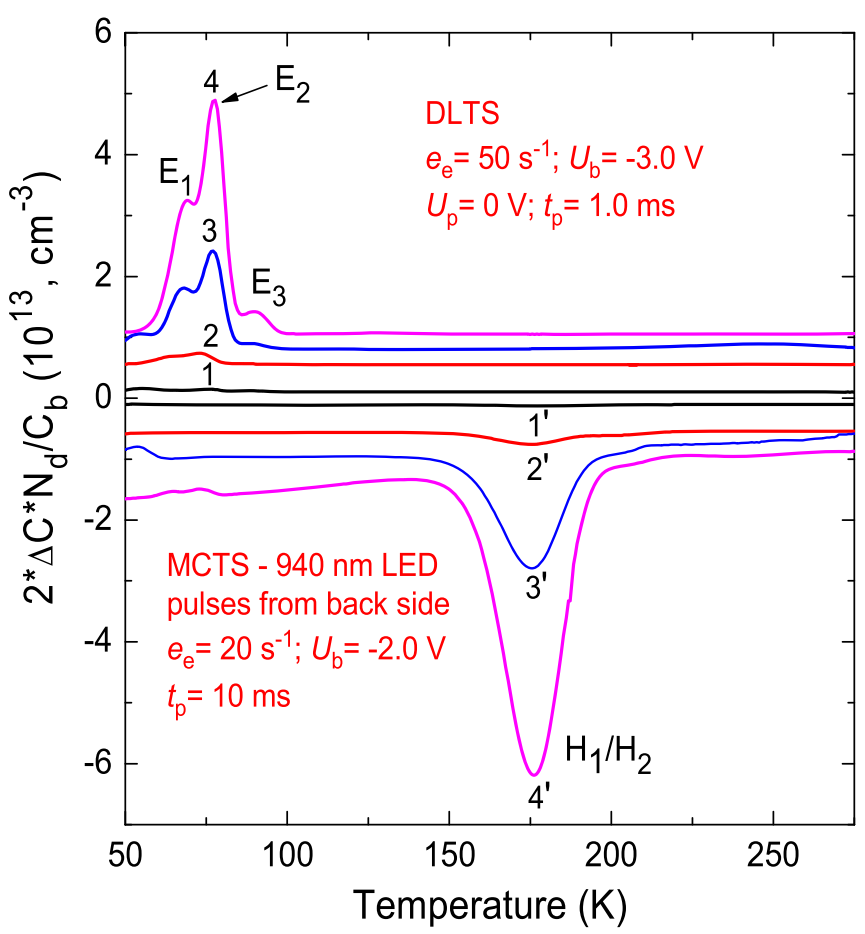

FIG. 4. DLTS (1 to 4 ) and MCTS ( $1^{\prime}$ to $4^{\prime}$ ) spectra for a set of four hydrogenated n-type Cz-Si samples with $\left[\mathrm{O}_{\mathrm{i}}\right] \sim 7.5 \times 10^{17} \mathrm{~cm}^{-3}$ and different $\left[\mathrm{C}_{\mathrm{s}}\right]$ : 1 , $1^{\prime}-0.01$ ppma; $2,2^{\prime}-0.1$ ppma; $3,3^{\prime}-1.2$ ppma; and $4,4^{\prime}-9$ ppma. The measurements parameters are given in the graph. The spectra are shifted on the vertical axis for clarity. Hydrogen was introduced into the sample by etching in $1 \mathrm{HF}+7 \mathrm{HNO}_{3}$ solution for $3 \mathrm{~min}$ at room temperature.

can be associated with two energy levels of two complexes each incorporating one oxygen, one carbon, and one hydrogen atom. We have argued in our previous study (Ref. 11) that the $\mathrm{H}_{1}$ and $\mathrm{H}_{2}$ hole traps are related to the first acceptor levels of two C-O-H complexes. So, if the $\mathrm{E}_{1} / \mathrm{H}_{1}$ and $\mathrm{E}_{2} / \mathrm{H}_{2}$ pairs are related to two energy levels of two $\mathrm{C}-\mathrm{O}-\mathrm{H}$ defects, it is reasonable to associate the $\mathrm{E}_{1}$ and $\mathrm{E}_{2}$ traps with the second acceptor levels of the defects.

We have carried out Laplace DLTS measurements of electron emission rates $\left(e_{\mathrm{n}}\right)$ and capture cross sections $\left(\sigma_{\mathrm{n}}\right)$ for the $E_{1}$ and $E_{2}$ traps to determine their electronic characteristics. From the Arrhenius plots of $\mathrm{T}^{2}$-corrected emission rates, we have derived the activation energies for the electron emission from the defect levels to the conduction band and pre-exponential factors as follows: $0.12 \pm 0.005 \mathrm{eV}$ and $3.3 \times 10^{7} \mathrm{~s}^{-1} \mathrm{~K}^{-2} ; 0.14 \pm 0.005 \mathrm{eV}$ and $2.1 \times 10^{7} \mathrm{~s}^{-1} \mathrm{~K}^{-2}$ for the $E_{1}$, and $E_{2}$ traps, respectively. From direct measurements of the majority carrier capture cross sections, we found the following $\sigma_{\mathrm{n}}$ values for the $\mathrm{E}_{1}$ and $\mathrm{E}_{2}$ traps $5.7 \times 10^{-16} \mathrm{~cm}^{2}$ and $7.35 \times 10^{-16} \mathrm{~cm}^{2}$, respectively. No significant temperature dependences of $\sigma_{\mathrm{n}}$ have been detected for both traps.

The $E_{1}$ and $E_{2}$ electron traps have been observed and characterized in previous works by Yoneta et al. ${ }^{24}$ and by Gwozdz et al. ${ }^{25}$ The results presented in Refs. 24 and 25 are, in general, consistent with our results on the $E_{1}$ and $E_{2}$ electron traps. There are, however, some discrepancies related to the identification of the charge state of the $E_{1}$ and $E_{2}$ traps. Yoneta et al. ${ }^{24}$ have said that "the results on depth profiles of these traps and carriers suggested the donor character of the traps, but they hardly exhibited the Poole-Frenkel effect."
On the other hand, Gwozdz et al. on the basis of their analysis of dependencies of electron emission rates from the $E_{1}$ and $E_{2}$ traps (labelled as E65 and E75 traps in Ref. 25) on the electric field strength have related these traps to single acceptor levels. $^{25}$ It should be noted that the values of the directly measured electron capture cross sections for the $E_{1}$ and $E_{2}$ traps given in Ref. $25\left(\sigma_{\mathrm{n}}=2 \times 10^{-18} \mathrm{~cm}^{2}\right.$ for both the traps) indicate the electron capture by a negatively charged defect (and so the second acceptor level) rather than a neutral one.

To obtain some further data to resolve the question regarding the charge state of the $E_{1}$ and $E_{2}$ traps, we have studied the dependencies of the electron emission rates from these traps on the electric field strength with the use of Laplace double DLTS technique. ${ }^{16}$ The obtained dependencies are shown in Fig. 6. It appears that the dependencies can be described well by a $e_{\mathrm{n}} \propto \exp \left(E^{2}\right)$ law, thereby indicating the phonon-assisted tunnelling as the mechanism for the electric field enhancement of electron emission. ${ }^{29,30}$ The phonon-assisted tunnelling has been shown to be the mechanism of the electric field enhancement of carrier emission for a number of defect levels related to the double to single charge state transitions in $\mathrm{Si}$ and $\mathrm{Ge} .^{31-33} \mathrm{So}$, the results obtained support our assignment of the $\mathrm{E}_{1}$ and $\mathrm{E}_{2}$ electron traps to the second acceptor levels of two C-O-H complexes.

The first principles calculations in Refs. 11 and 17 have revealed several possible structures of the $\mathrm{C}-\mathrm{O}-\mathrm{H}$ defect with the first acceptor in the lower part of the gap. The possible existence of a second acceptor level has not been calculated for these structures. So, further experimental and ab-initio

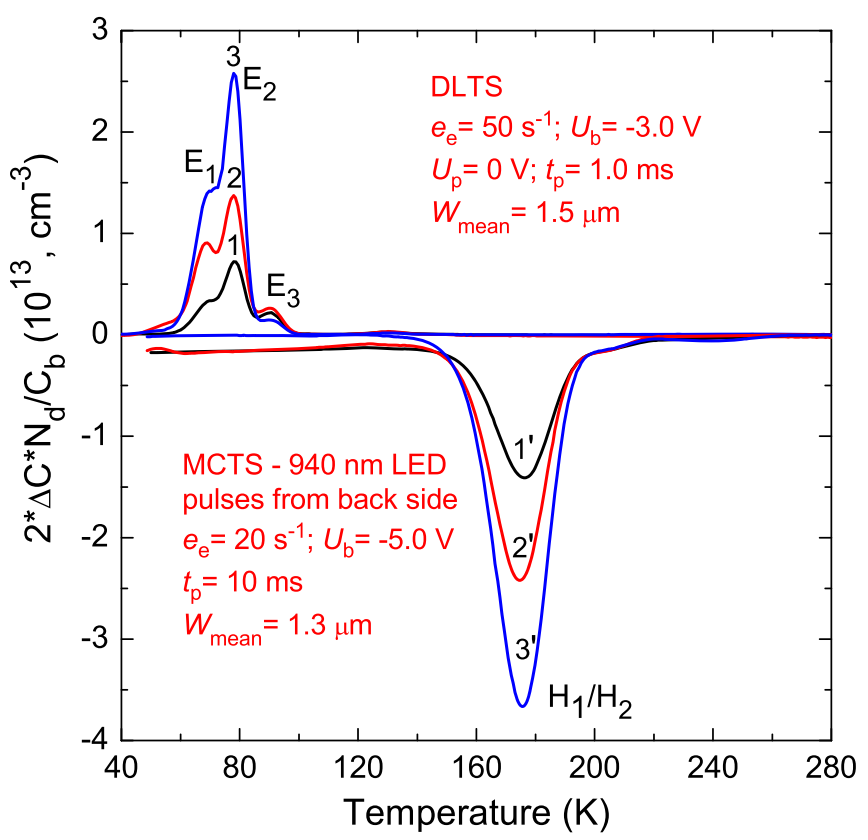

FIG. 5. DLTS (1 to 3 ) and MCTS ( $1^{\prime}$ to $\left.3^{\prime}\right)$ spectra for a set of three hydrogenated samples from n-type $\mathrm{Cz}-\mathrm{Si}$ material with $\left[\mathrm{O}_{\mathrm{i}}\right] \approx 7.5 \times 10^{17} \mathrm{~cm}^{-3}$ and $\left[\mathrm{C}_{\mathrm{s}}\right] \approx 4.5 \times 10^{17} \mathrm{~cm}^{-3}$. Before hydrogenation, the samples were subjected to the following heat-treatments: $1,1^{\prime}-0.5 \mathrm{~h}$ at $750^{\circ} \mathrm{C} ; 2,2^{\prime}-1.5 \mathrm{~h}$ at $500^{\circ} \mathrm{C}$; and $3,3^{\prime}-1 \mathrm{~h}$ at $550^{\circ} \mathrm{C}$. The measurements parameters are given in the graph. The spectra are shifted on the vertical axis for clarity. Hydrogen was introduced into the sample by etching in $1 \mathrm{HF}+7 \mathrm{HNO}_{3}$ solution for $3 \mathrm{~min}$ at room temperature. 

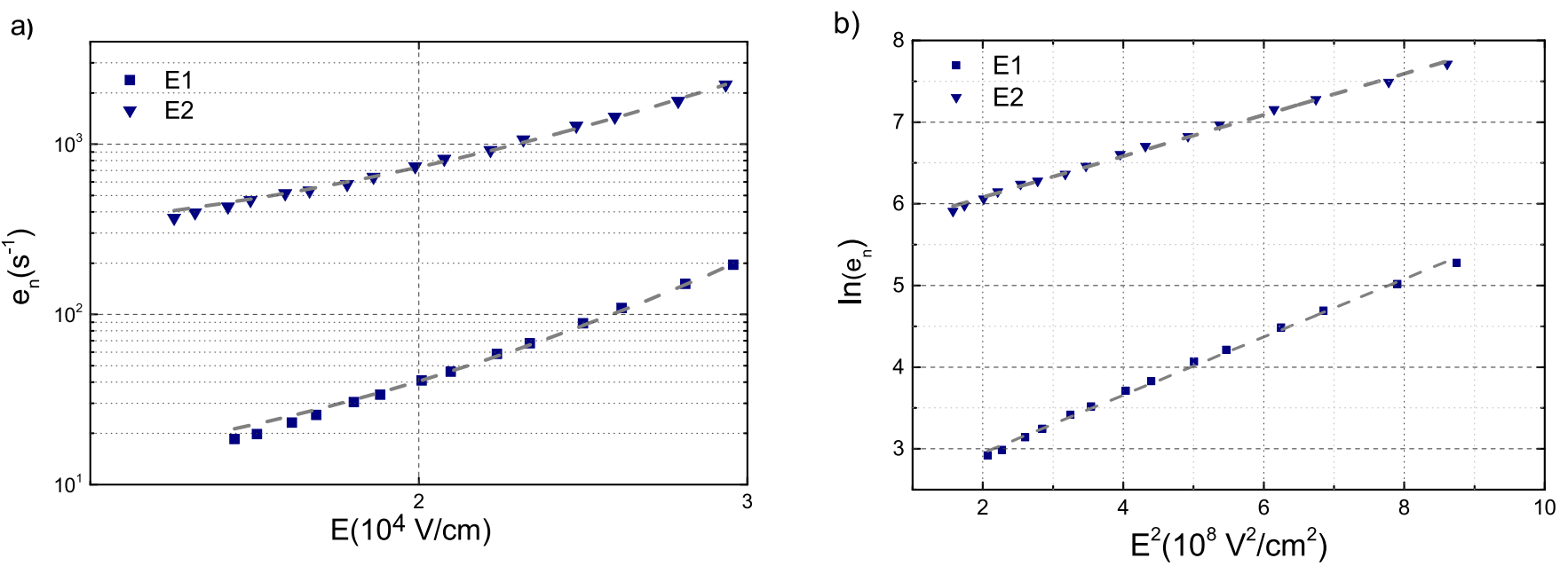

FIG. 6. Dependencies of the rate of electron emission, $e_{\mathrm{n}}$, on (a) electric field, and (b) $\ln \left(e_{\mathrm{n}}\right)$ on squared electric field for the $\mathrm{E}_{1}$ and $\mathrm{E}_{2}$ electron traps. The $e_{\mathrm{n}}$ values have been measured at $70 \mathrm{~K}$ for the $\mathrm{E}_{1}$ trap and at $80 \mathrm{~K}$ for the $\mathrm{E}_{2}$ trap with the use of Laplace double DLTS technique. The dashed lines in (a) represent the data fitted to $e(E)=e(0) \exp \left(E^{2} / E_{\text {ch }}^{2}\right)($ Refs. 29 and 30) and linear fits in (b).

modelling studies are needed to identify configurations and explain the electronic structures of the two C-O-H complexes responsible for the $\mathrm{E}_{1} / \mathrm{H}_{1}$ and $\mathrm{E}_{2} / \mathrm{H}_{2}$ electron/hole traps responsible for the lifetime degradation in hydrogenated n-type Si crystals containing a relatively large carbon concentration.

\section{CONCLUSIONS}

A number of minority and majority carrier traps are observed in phosphorous doped silicon containing oxygen and carbon impurity atoms after the introduction of hydrogen. Some of the traps act as powerful recombination centres, which severely decrease minority carrier lifetime in the $\mathrm{Si}: \mathrm{O}+\mathrm{C}$ materials. We demonstrate such an effect by $\mu \mathrm{PCD}$ mapping of the effective lifetime in a carbon and oxygen rich $\mathrm{Cz}-\mathrm{Si}$ sample, which was subjected to hydrogenation by four different techniques. The dominant recombination active defects are identified as two complexes each incorporating carbon, oxygen, and hydrogen atoms. Our results indicate that even though the defects are disassociated by heat-treatments at relatively low temperatures $\left(\sim 200^{\circ} \mathrm{C}\right)$, they are likely to reform upon cooling the samples down when enough hydrogen is retained in the silicon. Particularly, it is shown that such a scenario can be realized in the case of $\mathrm{Cz}-\mathrm{Si}$-based solar cells covered with $\mathrm{SiN}_{\mathrm{x}}: \mathrm{H}$ dielectric films, which are widely used in solar cell industry for anti-reflection and surface passivation purposes. The rise in $\mathrm{C}_{\mathrm{s}}$ concentrations in recent commercial $\mathrm{Cz}$ and $\mathrm{C}-\mathrm{Cz}$ solar silicon increases the probability of the formation of the C-O-H complexes and the associated decrease in efficiency of the solar cell produced from such materials. So, care should be taken for controlling the carbon concentration in solar grade silicon as it is one of the key parameters for the formation of the detrimental C-O-H traps.

\section{ACKNOWLEDGMENTS}

Special thanks are due to Dr. Ernie Hill and Maddison Coke for their support and advice during PECVD and plasma etch in the UK National Graphene Institute. The work was supported by the UK Engineering and Physical
Sciences Research Council (EPSRC) under the SuperSilicon PV Contract (EP/M024911/1). Financial support was also given by CONACyT-Mexico.

${ }^{1}$ A. B. Fowler, U.S. patent 3,849,204 (1974).

${ }^{2}$ A. R. Peaker, V. P. Markevich, and L. Dobaczewski, in Defects in Microelectronic Materials and Devices, edited by D. M. Fleetwood, S. T. Pantelides, and R. D. Schrimpf (CRC Press, Boca Raton, 2009), Chap. 2, pp. 27-56.

${ }^{3}$ C. Dubé, J. I. Hanoka, and D. B. Sandstrom, Appl. Phys. Lett. 44, 425 (1984).

${ }^{4}$ B. Sopori, J. Electron. Mater. 31, 972 (2002).

${ }^{5}$ G. Hahn and A. Schönecker, J. Phys.: Condens. Matter 16, R1615 (2004).

${ }^{6}$ L. J. Geerlings, Y. Komatsu, I. Röver, K. Wambach, I. Yamaga, and T. Saitoh, J. Appl. Phys. 102, 093702 (2007).

${ }^{7}$ B. J. Hallam, P. G. Hamer, S. R. Wenham, M. D. Abbott, A. Sugiantov et al., IEEE J. Photovoltaics 4, 88 (2014).

${ }^{8}$ N. Nampalli, B. Hallam, C. Chan, M. Abbott, and S. Wenham, Appl. Phys. Lett. 106, 173501 (2015).

${ }^{9}$ M. A. Green, Nat. Energy 1, 10015 (2016).

${ }^{10}$ V. P. Markevich, M. V. Contreras, J. Mullins, M. Halsall, B. Hamilton et al., in Proceedings of the 43rd IEEE Photovoltaic Specialists Conference (2016), pp. 688-693.

${ }^{11}$ M. Vaqueiro-Contreras, V. P. Markevich, M. P. Halsall, A. R. Peaker, P. Santos et al., Phys. Status Solidi RRL 11, 1700133 (2017).

${ }^{12}$ H. Xu, Energy Proc. 77, 658 (2015).

${ }^{13}$ A. ur Rehman and S. H. Lee, Sci. World J. 2013, 470347 (2013).

${ }^{14}$ N. Batra, S. Kumar, M. Sharma, S. K. Shrivastava, P. Sharma, and P. K. Singh, Sol. Energy Mater. Sol. Cells 100, 43 (2012).

${ }^{15}$ R. Brunwin, B. Hamilton, P. Jordan, and A. R. Peaker, Electron. Lett. 15, 349 (1979).

${ }^{16}$ L. Dobaczewski, A. R. Peaker, and K. B. Nielsen, J. Appl. Phys. 96, 4689 (2004).

${ }^{17}$ P. Santos, J. Coutinho, S. Oberg, M. Vaqueiro-Contreras, V. P. Markevich et al., Phys Status Solidi A 214, 1700309 (2017).

${ }^{18}$ L. C. Kimerling and J. L. Benton, Appl. Phys. Lett. 39, 410 (1981).

${ }^{19}$ D. I. Bohne and J. Weber, Phys. Rev. B 47, 4037 (1993).

${ }^{20}$ P. I. Rocket and A. R. Peaker, Appl. Phys. Lett. 40, 957 (1982).

${ }^{21}$ D. Stievenard and D. Vuillaume, J. Appl. Phys. 60, 973 (1986).

${ }^{22}$ J. A. Davidson and J. H. Evans, J. Appl. Phys. 81, 251 (1997).

${ }^{23}$ Y. Tokuda, I. Katoh, H. Ohshima, and T. Hattori, Semicond. Sci. Technol. 9, 1733 (1994).

${ }^{24}$ M. Yoneta, Y. Kamiura, and F. Hashimoto, J. Appl. Phys. 70, 1295 (1991).

${ }^{25}$ K. Gwozdz, R. Stübner, V. Kolkovsky, and J. Weber, Appl. Phys. Lett. 111, 32102 (2017).

${ }^{26}$ R. C. Newman and J. B. Willis, J. Phys. Chem. Solids 26, 373 (1965).

${ }^{27}$ Y. Shirakawa, H. Yamada-Kaneta, and H. Mori, J. Appl. Phys. 77, 41 (1995). 
${ }^{28}$ Y. Shirakawa and H. Yamada-Kaneta, J. Appl. Phys. 80, 4199 (1996).

${ }^{29}$ S. D. Ganichev, W. Prettl, and I. N. Yassievich, Phys. Solid State 39, 1703 (1997).

${ }^{30}$ S. D. Ganichev, E. Ziemann, W. Prettl, I. N. Yassievich, A. A. Istratov et al., Phys. Rev. B. 61, 10361 (2000).
${ }^{31}$ N. Zangenberg, J.-J. Goubet, and A. Nylandsted Larsen, Nucl. Instrum. Methods Phys. Res., Sect. B 186, 71 (2002).

${ }^{32}$ V. P. Markevich, A. R. Peaker, V. V. Litvinov, L. I. Murin, and N. V. Abrosimov, Physica B 376-377, 200 (2006).

${ }^{33}$ V. P. Markevich, A. R. Peaker, B. Hamilton, S. B. Lastovskii, and L. I. Murin, J. Appl. Phys. 115, 012104 (2014). 